\title{
The Impact of Research and Development on Productivity: Case of Turkey
}

\author{
Prof. Dr. Muammer Tekeoğlu (Çukurova University, Turkey) \\ Prof. Dr. Neşe Algan (Çukurova University, Turkey) \\ Asst. Prof. Dr. Erhan İşcan (Çukurova University, Turkey) \\ Ph.D. Candidate Duygu Serin Oktay (Çukurova University, Turkey)
}

\begin{abstract}
Productivity is one of the major research topics in economic literature because of the importance of sustainable development and growth for the countries. Besides, many of the theories stated that technology is the major source of productivity growth in the long run. Especially the productivity acceleration of the countries draw the attention of the researchers after the 90's due to the changes in the technology. Also, these changes expanded the productivity gap between countries in the consequences of changing growth pattern and increasing the size and structure of the economy. Therefore understanding the linkage between research and development and productivity becomes the most important research topic in the economic literature. Due to this importance analyzing the characteristics of productivity become an important issue for the policymakers for setting new policies. By virtue of the growing importance of understanding productivity changes of countries, the aim of this paper is to investigate the interaction between the research and development spending and productivity for Turkey. We used various types of research and development spending and productivity indicators to estimate this linkage using data for the last three decades. The importance of this paper is to clarify the effect of research and development impact on the productivity of Turkey. The results of this paper will enlighten the details of the underlying variables that affect productivity.
\end{abstract}

\section{Introduction}

There is a remarkable increase in productivity for all developing and developed economies in the last three decades. As mentioned in Frascati Manual (1963) research and development activities increased over time rapidly and this increase induced the economic growth through productivity for OECD members. OECD (2003) stated that productivity induced economic growth especially through the rise of information and communication technology. Therefore, in the empirical literature, productivity growth is still the main issue of the economic growth literature within the debates about cross-country productivity differentials and long-lasting effects of R\&D. Debates in the economic theory about the effect of technological progression started with Schumpeter (1934) and defined in his study technology as an important source of economic growth. In his seminal paper Solow (1956) emphasized the technological progress as a major determinant of the economic growth in a neoclassical framework and this emphasize directed the literature to a new pathway. Solow described the technological progress as an exogenous variable and stated that technological advancements promoted the economic growth for some economies. Besides, Lucas (1988) established an economic growth model that is introducing technological change as a key determinant. Likewise, Romer (1990) introduced a growth model that is driven by technological change. These models created the endogenous economic growth theoretical framework for the many types of research that are investigating the effect of the technological change on economic growth. Grossman and Helpman (1991a, 1991b) and Aghion and Howitt (1992, 1998) have emphasized importance of the technological progress through R\&D in their papers for achieving a long-term economic growth with generating spillovers to economy. Especially $R \& D$ is the key for industrial innovation as the main promoter of economic growth and therefore $R \& D$ expenditures have a positive effect on economic progression with increasing output through increasing productivity.

Innovation and technology are very sensitive to R\&D expenditure for producing high value-added goods and services. Besides, innovation and technology is a key element to increase productivity for promoting economic growth. The strong economic growth of the developed and emerging countries after the 1990s showed us the importance of the effect of technology and innovation for productivity growth in the long run. Similarly, developing countries with lower technology that is a boundary for the productivity increase is decoupling from the others. Many researchers asserted that among the other reasons of low productivity like institutional framework, lower quality of the labor and lack of resources, lower technology with lower R\&D expenditure caused the low rate of economic growth.

In the current literature, many of the researchers' found that R\&D spendings as the main promoter for the productivity and cause of the cross-country differences by using various techniques with different country data. In this framework, the main aim of this study is to analyze the effect of R\&D spendings on productivity for Turkey. For this purpose, there will be a detailed analysis of the impact of R\&D on productivity with the R\&D and productivity dataset by using the ARDL technique. In the second section, there will be a view of R\&D spendings and productivity of Turkey. In the third section, the current literature will be analyzed. In the fourth section, 
method, model, and dataset will be introduced. Results will be given in the fifth section and there will be a conclusion in the last section.

\section{R\&D Expenditure and Productivity in Turkey}

Many of the researches in the literature pointed out the productivity changes in an economy induced by R\&D spendings and emphasized as a key component of technological progress for promoting economic growth. Especially the substantial increase in the productivity of European countries and the US drew attention to the impact of R\&D. The case is also similar for Turkey and the data showed a substantial increase in productivity after the 1990s. Besides, R\&D started to increase at the beginning of the 2000 s and reached to $1 \%$ of GDP while the average of OECD is about $2.5 \%$.

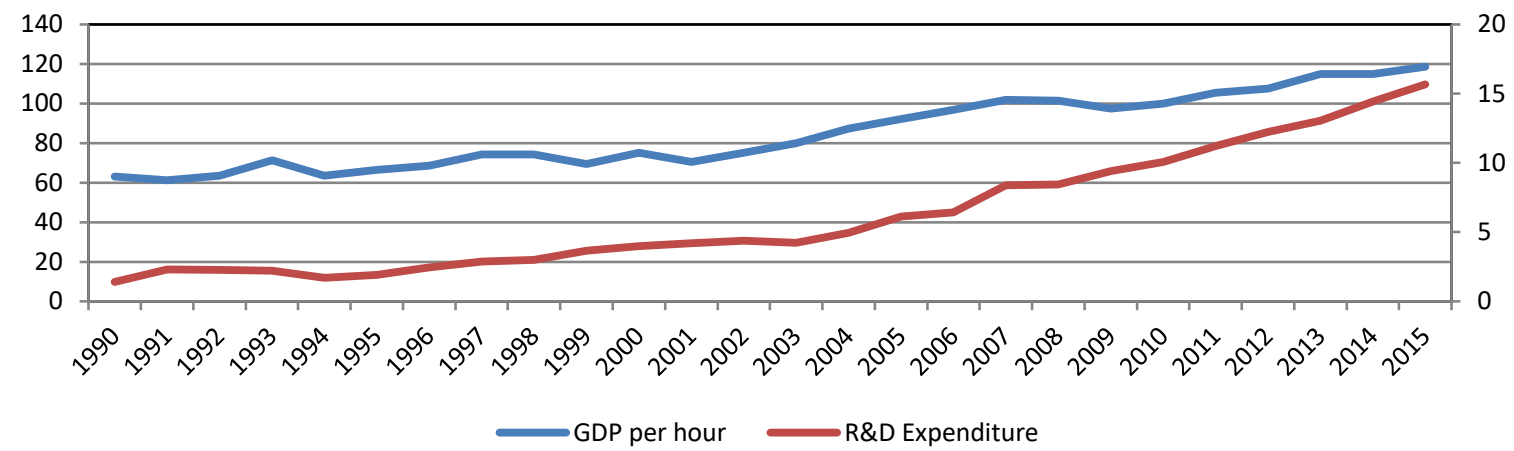

Graph 1: GDP per Hour Worked and Gross Domestic Expenditure on R\&D

R\&D investments are considered as one of the key criteria in evaluating the competitiveness and economic development of a country. Especially, one of the main factors that promote economic growth in developed economies is the innovation of new products and techniques. In this context, due to the importance of R\&D expenditure for the innovation gross domestic spending on R\&D as \%of GDP will reflect the decoupling of the developed countries. Share of the R\&D expenditure is very low from the OECD average in Turkey and implied the results.

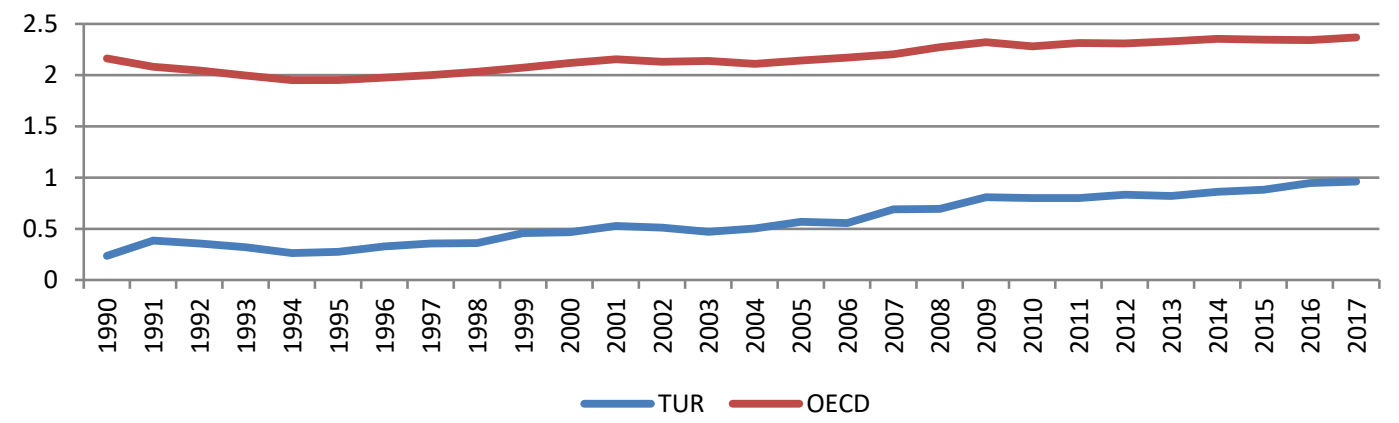

Graph 2: Gross Domestic Spending on R\&D as \% of GDP

\section{Literature Review}

There are a large number of studies in the literature on the analysis of causality and relations between R \& D, patent, innovation, export, and growth. These researches in the current literature have studied the effect of the R\&D on productivity by using various techniques and found different results. Although there is a wide difference between these results of the studies, they revealed the importance of the R\&D for the productivity growth and economic progress within the technological change. But, there is no consensus on the impact of R\&D thus explanations are quite ambiguous for this interaction. Different countries with different levels of $R \& D$ expenditures, different periods with different sectors and different models with variables brought the different results. The main line of the literature stated that technological development and innovation increase export growth and economic growth, while increasing profits and market share of firms. Therefore R\&D expenditures have indirect effect to affect economic growth.

Lichtenberg (1993) analyzed the relationship between private and public sector R\&D expenditures and economic growth and results showed that there is a relationship between R \& D expenditures and growth in the private sector and there is no such relationship in the public sector. Hall and Mairesse (1992) analyzed the relationship between 
R\&D and productivity in their paper and found a positive impact on R\&D expenditures. Griffith, Redding, and Van Reenen (2004) analyzed the impact of R\&D by using the data of 12 OECD countries and found that R\&D is the key to the innovation for economic progression. Rouvinen (2002) conducted research for the OECD countries and found a positive impact of R\&D expenditures. Fikirli and Çetin (2015) analyzed the relationship between $R \& D$ capital stock and total factor productivity and found that R\&D expenditure does not have statistically significant effects on TFP during the period of analysis. Edquist and Henrekson (2017) analyzed the effect of R\&D and ICT on total factor productivity for Sweden and found that R\&D is significantly associated with productivity growth. Besides, there is no significant short-run association between ICT and TFP but a positive association with a lag of seven to eight years. Castellani et. al (2019) investigates the sources of the US/EU productivity gap by using data on the US and EU R\&D expenditures from 2004 to 2012 and found that US firms have higher R\&D impact on productivity than EU firms.

\section{Dataset and Method}

The annual dataset in this analysis was gathered from OECD.stat and consists of Turkey's R\&D expenditure and GDP per hour worked as a proxy for productivity for the period between 1990 and 2015. ARDL bound test method is used to analyze the relationship between these two variables. The variables used in the model and their definitions are as follows.

RDEXP: Gross domestic expenditure on R\&D by sector of performance and type of expenditure. R\&D is in constant prices and PPPs.

GDPPHW: GDP per hour worked. This can be achieved if more capital is used in production or through improved overall efficiency with which labor and capital are used together, i.e., higher multifactor productivity growth (MFP). GDP per hour worked is an index and 2010 is the base year.

Logarithmic transformations of the data sets used in the study were made and conducted a unit root test to determine the order of integration for each variable. Then the ARDL method is employed to determine the relationship between the variables. ARDL method has two advantages for our study. First one is about the integration order of the variables and the second one is the size of the sample. Because of these two advantages, the ARDL method is employed in this study.

\section{Results}

In this study, it was determined that the series were stationary or not and KPSS test is used to investigate the stationary properties of the variables. KPSS test results are as follows. For the KPSS test, the lags were based on bandwidth Newey-West using Bartlett kernel. The critical values for the KPSS test are from Kwiatkowski et al. (1992). KPSS unit root test results indicated that the ARDL method can be used for analyzing the relationship. Even though ARDL method does not require testing for the unit root for stationary, variables must be analyzed for I(2) for using the ARDL method.

\begin{tabular}{|l|l|l|l|l|l|}
\hline \multicolumn{2}{|c|}{} & LM-Stat & $\begin{array}{l}\text { Asymptotic Critical } \\
\text { Values 1\% }\end{array}$ & $\begin{array}{l}\text { Asymptotic Critical } \\
\text { Values 5\% }\end{array}$ & $\begin{array}{l}\text { Asymptotic Critical } \\
\text { Values 10\% }\end{array}$ \\
\hline \multirow{2}{*}{ Level } & \multirow{2}{*}{ T } & 0.712651 & 0.739 & $0.463 *$ & 0.347 \\
\cline { 3 - 6 } 1. Difference & 0.200134 & 0.216 & $0.146^{*}$ & 0.119 \\
\hline \multirow{2}{*}{ Level } & \multirow{2}{*}{ T\&I } & 0.568075 & 0.739 & $0.463^{*}$ & 0.347 \\
\cline { 3 - 6 } 1. Difference & 0.065563 & 0.216 & 0.146 & 0.119 \\
\hline
\end{tabular}

Table 1: KPSS Unit Root Test Results for RDEXP

\begin{tabular}{|l|l|l|l|l|l|}
\hline \multicolumn{2}{|c|}{} & LM-Stat & $\begin{array}{l}\text { Asymptotic Critical } \\
\text { Values 1\% }\end{array}$ & $\begin{array}{l}\text { Asymptotic Critical } \\
\text { Values 5\% }\end{array}$ & $\begin{array}{l}\text { Asymptotic Critical } \\
\text { Values 10\% }\end{array}$ \\
\cline { 1 - 5 } Level & \multirow{2}{*}{$\mathrm{T}$} & 0.733047 & 0.739 & $0.463 *$ & 0.347 \\
\cline { 3 - 6 } 1. Difference & 0.140975 & 0.216 & 0.146 & $0.119^{*}$ \\
\hline \multirow{2}{*}{ Level } & \multirow{2}{*}{ T\&I } & 0.173010 & 0.739 & 0.463 & 0.347 \\
\cline { 3 - 6 } 1. Difference & 0.064856 & 0.216 & 0.146 & 0.119 \\
\hline
\end{tabular}

Table 2: KPSS Unit Root Test Results for GDPPHW

The first step of the ARDL model is to determine the appropriate lag length. In the study, since the number of observations was limited the maximum lag length was taken as three. For the ARDL boundary test, the F statistic was calculated to test the cointegration relationship. If the F statistic is greater than the critical upper limit, the cointegration relationship exists between the series and if it falls below the lower critical value, the cointegration relationship is decided. If the F statistic falls between the lower and upper critical values, then a final decision cannot be made. 


\begin{tabular}{|c|c|c|c|c|c|}
\hline \multirow[t]{2}{*}{ F-statistic } & \multicolumn{2}{|c|}{$\begin{array}{l}\text { Bound critical values (unrestricted } \\
\text { constant and no trend) }\end{array}$} & \multirow[t]{2}{*}{ F-statistic } & \multicolumn{2}{|c|}{$\begin{array}{l}\text { Bound critical values } \\
\text { (restricted intercept and trend) }\end{array}$} \\
\hline & $\mathrm{I}(0)$ & $\mathrm{I}(1)$ & & $\mathrm{I}(0)$ & $\mathrm{I}(1)$ \\
\hline 4.587632 & & & 2.249870 & & \\
\hline \begin{tabular}{l|l|} 
& $1 \%$ \\
\cline { 2 - 2 }
\end{tabular} & 6.84 & 7.84 & \begin{tabular}{l|l|}
$1 \%$ \\
\end{tabular} & 6.1 & 6.73 \\
\hline $5 \%$ & 4.94 & 5.73 & $5 \%$ & 4.68 & 5.15 \\
\hline $10 \%$ & 4.04 & 4.78 & $10 \%$ & 4.05 & 4.49 \\
\hline
\end{tabular}

Table 3: F-Statistic of a Cointegration Relationship

The cointegration relationship between the variables was investigated and it was concluded that there is no longterm relationship between GDPPHW and RDEXP series. Therefore, the ARDL boundary test approach did not proceed to other stages where long and short term elasticities were obtained respectively.

\section{Conclusion}

The main aim of this study is to analyze the impact R\&D expenditures on the productivity that is essential for economic progression. Although many of the researchers have found a positive impact of R\&D on productivity, there is no such relationship for Turkey. The reason for this kind of result is in fact not a surprise. In the literature, many of the researches stated that import of technology, human capital or organizational and managerial innovations may be the main promoter of productivity growth. The main reason for this result may be the low R\&D expenditure of Turkey. The ratio of total R\&D expenditure is lower than OECD average and developed countries within the differences of characteristics that are promoting productivity.

\section{References}

- Aghion, Philippe, and Peter Howitt. "The Schumpeterian approach to technical change and growth." Economic Growth in the World Economy: Symposium. Vol. 1993. 1992.

- Castellani, Davide, et al. "R\&D and productivity in the US and the EU: Sectoral specificities and differences in the crisis." Technological Forecasting and Social Change 138 (2019): 279-291.

- Edquist, Harald, and Magnus Henrekson. "Do R\&D and ICT affect total factor productivity growth differently?." Telecommunications Policy 41.2 (2017): 106-119.

- Edquist, Harald, and Magnus Henrekson. "Swedish lessons: How important are ICT and R\&D to economic growth?." Structural Change and Economic Dynamics 42 (2017): 1-12.

- $\quad$ Fikirli, Özlem, and Ahmet Kibar Çetin. "Ar-Ge Sermaye Birikiminin Toplam Faktör Verimliliğine Etkisi: Türkiye Örneği." Girişimcilik ve İnovasyon Yönetimi Dergisi 4.2 (2015): 147-166.

- Griffith, Rachel, Stephen Redding, and John Van Reenen. "Mapping the two faces of R\&D: Productivity growth in a panel of OECD industries." Review of economics and statistics 86.4 (2004): 883-895.

- Grossman, Gene M., and Elhanan Helpman. "Trade, knowledge spillovers, and growth." European economic review 35.2-3 (1991): 517-526.

- Grossman, Gene M., and Elhanan Helpman. Innovation and growth in the global economy. MIT press, 1991.

- Hall, Bronwyn H., and Jacques Mairesse. "Exploring the Relationship Between R\&D and Productivity at the Firm Level in French Manufacturing." (1992).

- Howitt, Peter, and Philippe Aghion. "Capital accumulation and innovation as complementary factors in long-run growth." Journal of Economic Growth 3.2 (1998): 111-130.

- Lichtenberg, F.R. (1993), “R\&D Investment and International Productivity Differences”, NBER Working Paper Series, No. 4161.

- $\quad$ Lucas Jr, Robert E. "On the mechanics of economic development." Journal of monetary economics 22.1 (1988): 3-42.

- $\quad$ OECD. "Frascati Manual 1992." (1992).

- OECD (1993), The Measurement of Scientific and Technological Activities: Standard Practice for Surveys of Research and Experimental Development - Frascati Manual 1993, OECD, Paris.

- $\quad$ Romer, Paul M. "Endogenous technological change." Journal of political Economy 98.5, Part 2 (1990): S71S102.

- $\quad$ Rouvinen, Petri. "The existence of R\&D spillovers: A cost function estimation with random coefficients." Economics of Innovation and New Technology 11.6 (2002): 525-541.

- Schumpeter, J.A. (1934) The Theory of Economic Development: An Inquiry into Profits, Capital, Credits, Interest, and the Business Cycle. Transaction Publishers, Piscataway. 
- Solow, Robert M. "A contribution to the theory of economic growth." The quarterly journal of Economics 70.1 (1956): 65-94.

- Solow, Robert M. "A contribution to the theory of economic growth." The quarterly journal of economics 70.1 (1956): 65-94. 